\title{
Water Pollution in an Urban Argentine River
}

\author{
A. Magdaleno, ${ }^{1}$ A. Puig, ${ }^{2}$ L. de Cabo, ${ }^{2}$ C. Salinas, ${ }^{2}$ S. Arreghini, ${ }^{2,3}$ S. Korol, ${ }^{4}$ \\ S. Bevilacqua, ${ }^{4}$ L. López, ${ }^{4}$ J. Moretton ${ }^{4}$ \\ 1 Department of Biological Sciences, University of Buenos Aires, Pab. II, Ciudad \\ Universitaria, C1428EHA Buenes Aires, Argentina \\ 2 Limnology Division, Argentine Museum of Natural Sciences "B. Rivadavia" and \\ National Research Institute of Natural Science, Angel Gallardo 470, C1405DJR \\ Buenos Aires, Argentina \\ 3 Scientific Research Commission (CIC), La Plata, Argentina \\ 4 Hygiene and Public Health, University of Buenos Aires, Junín 956, Piso $4^{\circ}$, \\ C1113AAC Buenos Aires, Argentina
}

Received: 10 January 2001/Accepted: 31 May 2001

Chemical stress in aquatic ecosystems is increasing. Water pollution assessment, and its possible effects upon river biotic communities, is required for development of control and management strategies. The Matanza-Riachuelo, a temperate lowland river, is one of the most polluted rivers of Latin America (Olson et al. 1998), representing a risk for human health. Its mixed pollution derives from farming, grazing, and wastewater from domestic sewage and thousands of industries. River waters flow into the Rio de la Plata, a binational estuary, main source of drinking water for Buenos Aires city and environs.

The aim of the present paper is to evaluate the water pollution condition throughout the main channel of the river by multiple approaches: estimation of physicochemical variables, analysis of density of the main groups of phyto- and zooplankton, and biological tests of algal growth inhibition by heavy metals and of genotoxic effects on a bacterium.

\section{MATERIALS AND METHODS}

The Matanza-Riachuelo River (Buenos Aires, 35 $06^{\prime}-34^{\circ} 38^{\prime} \mathrm{S}$ and $58^{\circ} 49^{\prime}-58^{\circ} 21^{\prime} \mathrm{W}$ ) belongs to a densely populated basin (1,100 inhabitants per sq $\mathrm{km}$ ). Mid-main channel water samples were collected monthly, from December 1996 to November 1997, in five river sites ( $\mathrm{S} 1$ to $\mathrm{S} 5$ ) (Fig. 1). S1 is located in a zone of intensive and extensive agriculture; in S2 the land use is shared by farming and urbanization, mostly lacking sewerage system; in S3 the river runs through an extensive woodland; S4 and S5 are exposed to the heaviest industrial impact (mainly tanneries, and meat, food, chemical, and metallurgic industries) and to the most dense population of the country, mainly with sewerage. From S3 to S5 the river is bypassed by two successive channelings.

Temperature, $\mathrm{pH}$ (pH-meter), and conductivity were measured in situ. Water was sampled for: dissolved oxygen (DO) (Winkler's method), chemical oxygen demand (COD) (closed reflux method), biochemical oxygen demand $\left(\mathrm{BOD}_{5}\right)$, particulate organic carbon (POC) (Golterman et al. 1978), suspended matter (SM) (gravimetry) and total heavy metals. Water samples were filtered in situ through Whatman GF/C filters and transported to the laboratory at $4^{\circ} \mathrm{C}$ for analysis of soluble forms: soluble reactive phosphorus (SRP) (molybdate-ascorbic), nitrates $\left(\mathrm{NO}_{3}^{-}-\mathrm{N}\right)$ (hydrazine sulphate), nitrites $\left(\mathrm{NO}_{2}^{-}-\mathrm{N}\right)$ (diazotation), ammonium $\left(\mathrm{NH}_{4}^{+}-\mathrm{N}\right)$ (indophenol blue), calcium $\left(\mathrm{Ca}^{2+}\right)$, magnesium $\left(\mathrm{Mg}^{2+}\right)$ (Ethylenediamine-tetraacetic acid), bicarbonate $\left(\mathrm{HCO}_{3}\right)$ (heliantine titration), sulphate $\left(\mathrm{SO}_{4}^{2}\right)$ (turbidimetry), chloride $(\mathrm{Cl})$ (silver nitrate titration), and dissolved heavy metals. DIN (dissolved inorganic nitrogen) was calculated 


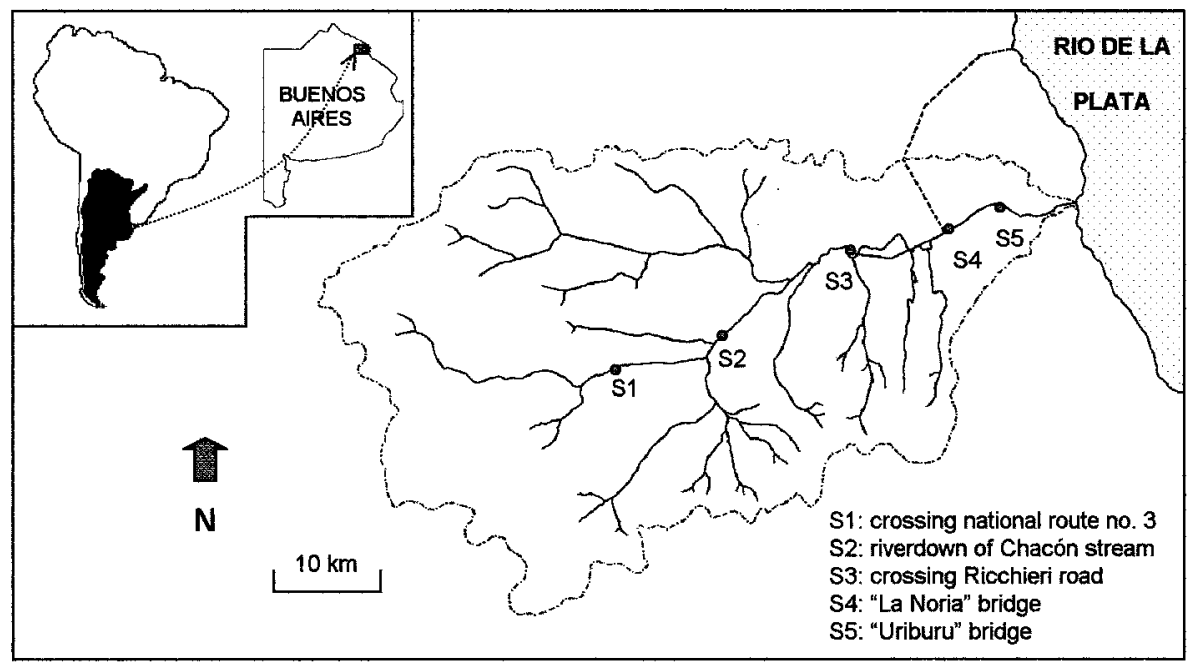

Figure 1. Map of the Matanza-Riachuelo River showing the location of sampling sites.

as the sum of $\mathrm{NH}_{4}^{+}-\mathrm{N}, \mathrm{NO}_{3}^{-}-\mathrm{N}$, and $\mathrm{NO}_{2}^{-}-\mathrm{N}$. Heavy metal samples were immediately acidified with concentrated nitric acid to $\mathrm{pH}<2$. Copper, lead, zinc, iron, manganese, cadmium, chromium, and nickel, at soluble and total fractions, were measured by atomic absorption spectrophotometry. All physical and chemical analyses followed APHA (1995).

Four river sites (S1 to S4) were studied for phytoplankton. Subsurface water samples (150 mL) were fixed with $4 \%$ Lugol solution for quantitative analysis. Samples for taxonomical analysis were collected with a $25-\mu \mathrm{m}$ mesh net and fixed with $3 \%$ formalin. Five-mL subsamples were counted following Utermöhl (1958) method. The number of random fields to be counted from each chamber was calculated according to Sournia (1978), to keep the error of density estimations of the most abundant algal class below 15\%. Algal densities are expressed as individuals per $\mathrm{mL}$ (ind. $\mathrm{mL}^{-1}$ ). Unicellular organisms likewise colonial and filamentous algae were considered as counting units. Zooplankton samples were collected by filtering 80 litres of subsurface water through a $48-\mu \mathrm{m}$ mesh net and fixed in situ with $3-5 \%$ formalin. Five-mL subsamples were taken with a Hensen-Stempel pipette and fully counted in a Bogorov chamber using a stereoscopic microscope (up to 100 magnifications), following Lewis (1979) counting rules. The densities of the main groups are expressed as individuals per liter (ind. $\mathrm{L}^{-1}$ ).

Algal assays were performed using the green alga Selenastrum capricornutum Printz (CCAP No. 278/4). The water samples were filtered through $0.45-\mu \mathrm{m}$ membrane filters. One $\mathrm{mg} \mathrm{L}^{-1}$ of EDTA (ethylenediamine-tetraacetic acid) was added to one part of the filtered water to complex the dissolved heavy metals. Another filtered river water subsample, without EDTA, was used as a control. Triplicate $125-\mathrm{mL}$ glass Erlenmeyer flasks containing $25 \mathrm{~mL}$ of filtrate were inoculated with the algal strain to nominal concentration of $5 \times 10^{4}$ cell mL $\mathrm{mL}^{-1}$. The tests were conducted under $24-26^{\circ} \mathrm{C}, 23 \mu \mathrm{E} \mathrm{m}{ }^{-2} \sec ^{-1}$ of continuous "cool-white" fluorescent light, and the flasks were manually shaken twice a day. Algal growth was estimated by absorbance $(750 \mathrm{~nm})$ (USEPA 1994) with respect to reading blank (control without inoculum), at day 8. Cell density was estimated by means of a calibration curve. Heavy metal toxicity results are expressed as percentage of inhibition (\%), based on the difference in cell density obtained in the control and 
that of the sample containing EDTA, according to Miller et al. (1978). Triplicate genotoxicity tests was performed with samples from S2, S4, and S5 in June and August, following Maron and Ames (1983). The strains TA98 and TA100 of Salmonella typhimurium, with and without microsome activation, were used. A subsample of each water sample was assayed after filtration $(0.22-\mu \mathrm{m}$ pore membranes) and other subsample was assayed after extraction by XAD2 resins (Vázquez and Moretton 1995). The criterion of positive results was that defined by Maron and Ames (1983): twofold or greater increase in the number of revertants exposed to the test material over spontaneous reversion rates.

A local index of water quality (ICA), that evaluates organic pollution considering temperature, $\mathrm{Cl}^{-}, \mathrm{NH}_{4}^{+}-\mathrm{N}, \mathrm{BOD}_{5}$, and DO (Berón 1984), was applied. It varies between 0 (worst condition) and 10 (best condition). Correlation analyses among space-time series of biotic and abiotic variables (Xanthophyceae, Dinophyceae, Calanoida, and $\mathrm{Cr}$ excluded) were performed using the Spearman's rank correlation coefficient, considering a $\mathrm{P}<0.05$.

\section{RESULTS AND DISCUSSION}

In the Matanza-Riachuelo River DO levels were low, particularly in stations S2 and S4, reaching the anoxic condition in S5 (Table 1). Conductivity values were high in all sampling sites, whereas $\mathrm{pH}$ remained close to neutrality. Temperature variations responded to the seasonal factor (winter mean: $13.2^{\circ} \mathrm{C}$ and summer mean: $23.9{ }^{\circ} \mathrm{C}$ ). Ammonium represented $83.5 \%$ of DIN, showing higher percentages in S2 (92\%), S4 (96\%), and S5 (97\%). Ammonium, $\mathrm{BOD}_{5}, \mathrm{COD}, \mathrm{Cl}$, and conductivity tended to increase toward the river mouth, whereas DO, $\mathrm{NO}_{3}-\mathrm{N}$, and $\mathrm{NO}_{2}-\mathrm{N}$ tended to decrease, showing all a slight improvement in $\mathrm{S} 3$ (Table 1), at the beginning of the channeling, where the river runs through an extensive woodland. A decrease in concentration of $\mathrm{Cl}^{-}, \mathrm{Ca}^{2+}, \mathrm{SO}_{4}{ }^{2-}$, and $\mathrm{Mg}^{2+}$ was observed in $\mathrm{S} 5$ with respect to $\mathrm{S} 4$ (Table 1), probably owing to the diluting effect produced by the Rio de la Plata waters. The organic pollution was high in the study river (mean ICA index: 2.5); relatively lower in S1, followed by S3, and likewise higher in S4 and S5 (Table 1). Dissolved oxygen was positively correlated with $\mathrm{NO}_{3}^{-}-\mathrm{N}, \mathrm{NO}_{2}^{-}-\mathrm{N}, \mathrm{HCO}_{3}^{-}$, and $\mathrm{pH}$, and negatively with $\mathrm{NH}_{4}^{+}-\mathrm{N}, \mathrm{BOD}_{5}, \mathrm{COD}, \mathrm{POC}, \mathrm{Cl}^{-}$, and $\mathrm{Ca}^{2+}$ (Table 2). The COD/BOD 5 ratios around 4 (Braile and Cabalcanti 1993) and the positive correlation observed between COD and SM (Table 2) denoted a great proportion of nonbiodegradable complex particulate organic matter, such as hydrocarbons, especially in $\mathrm{S} 4$ and S5. In these sites, POC values were higher, and SM lower, than those estimated for the 19951996 period (López et al. 1998). The values of $\mathrm{Cl}^{-}$, conductivity, $\mathrm{NH}_{4}^{+}-\mathrm{N}$, and $\mathrm{NO}_{2}^{-}-\mathrm{N}$ were higher and those of $\mathrm{DO}$, and $\mathrm{NO}_{3}-\mathrm{N}$ lower than records from Reconquista River (Castañé et al. 1998), another highly polluted urban river, similar in geomorphological and climatic watershed characteristics.

Phytoplankton (mean: 25,000 ind. $\mathrm{mL}^{-1}$ ) and zooplankton (mean: 534 ind. $\mathrm{L}^{-1}$ ) densities were high, exceeding by an order of magnitude the mean records from Reconquista River (Castañé et al. 1998) (Table 3). Cyanophyceae (38\%), Chlorophyceae (33\%), Bacillariophyceae (23\%) and Euglenophyceae $(10 \%)$ were the dominant algal classes. Abundance of Cyanophyceae, Chlorococcales (75\% of Chlorophyceae), and Euglenophyceae denoted very eutrophic conditions (Angeli 1979). Cyanophyceae were also favored by the low flow (Descy 1987) of this river. Rotifers were widely dominant $(99 \%)$ in zooplankton, exceeding the percentage from Reconquista River. Such a notable proportion may reflect a pollution effect, since some chemicals have lethal toxicity for crustacean zooplankters but not for rotifers (Hanazato and Yasumo 1990), and there are rotifers that may feed exclusively on bacteria, which are favored 
Table 1. Annual mean and range of physical and chemical parameters. Variables are expressed in $\mathrm{mg} \mathrm{L}^{-1}$, except for temperature $\left({ }^{\circ} \mathrm{C}\right)$ and conductivity $\left(\mathrm{mS} \mathrm{cm}{ }^{-1}\right)$. ICA: water quality index.

\begin{tabular}{|c|c|c|c|c|c|}
\hline & S1 & $\mathrm{S} 2$ & S3 & $\$ 4$ & S5 \\
\hline$\overline{\mathrm{DO}}$ & $3.7(1.3-6.9)$ & $1.2(0-3.6)$ & $5.8(2.1-12)$ & $0.5(0-3.4)$ & $0(0.0-0.0)$ \\
\hline Temperature & $17(7-25)$ & $18(8-26)$ & $21(10-30)$ & $22(12-30)$ & $22(14-30)$ \\
\hline $\mathrm{pH}$ & $7.6(7.3-7.9)$ & $7.6(7-8.20)$ & $7.8(7-8.5)$ & $7.3(6.6-8.1)$ & $7.2(6.7-8)$ \\
\hline Conductivity & $1.7(1.1-2.1)$ & $1.9(1-2.5)$ & $1.4(1-1.7)$ & $1.8(1.27-3.40)$ & $1.7(1.13-2.60)$ \\
\hline SM & $22.3(9-52)$ & $30.3(19.7-44)$ & $43.6(6-97.7)$ & $37.3(19-53)$ & $34.5(16.7-47.3)$ \\
\hline $\mathrm{NH}_{4}{ }^{+}-\mathrm{N}$ & $5.5(0-21.8)$ & $13.2(4.14-21)$ & $6.7(2.9-14.2)$ & $13.1(7.7-19)$ & $15(6-22.2)$ \\
\hline $\mathrm{NO}_{2}^{-}-\mathrm{N}$ & $0.6(0.1-1.8)$ & $0.2(0.04-0.5)$ & $0.3(0.02-0.6)$ & $0.2(0.01-1.60)$ & $0.1(0.01-0.90)$ \\
\hline $\mathrm{NO}_{3}^{-}-\mathrm{N}$ & $1.7(0.2-5.3)$ & $0.7(0.02-2.7)$ & $1.3(0.03-3.3)$ & $0.3(0-1.40)$ & $0.2(0-1.5)$ \\
\hline DIN & 7.9 & 14.1 & 8.3 & 13.6 & 15.4 \\
\hline SRP & $2.6(1.1-3.3)$ & $3.1(1.3-4.7)$ & $2.7(1-4.5)$ & $2.7(1.15-4.5)$ & $2.7(1.4-3.7)$ \\
\hline POC & $19.2(7-38.1)$ & $25.1(7.1-53.5)$ & $23.9(5.5-51)$ & $27.9(9.2-48.6)$ & $27(9-46.2)$ \\
\hline $\mathrm{COD}$ & $79.8(42-270)$ & $113(58-220)$ & $76.3(62-94)$ & $146.8(104-270)$ & $173(130-250)$ \\
\hline $\mathrm{BOD}_{5}$ & $22.9(10-70)$ & $24.9(10-50)$ & $16.4(10-30)$ & $31(20-40)$ & $37.9(10-80)$ \\
\hline $\mathrm{Ca}^{2+}$ & $37.9(17.6-48.1)$ & $44.8(25.1-58.2)$ & $41.7(31.1-51)$ & $50.5(37.8-87.6)$ & $47.4(32-63.7)$ \\
\hline $\mathrm{Mg}^{2+}$ & $24.9(8.3-34.9)$ & $25.9(13.6-35.7)$ & $26.4(8.8-63.9)$ & $33.5(11-84.5)$ & $23.6(8.5-45)$ \\
\hline $\mathrm{SO}_{4}{ }^{2-}$ & $88.5(42.5-191)$ & $110.8(50-225)$ & $72.3(39.6-141)$ & $81.7(57-142.5)$ & $78.7(30-144.4)$ \\
\hline $\mathrm{HCO}_{3}^{-}$ & $709(26.9-925)$ & $815.6(448-1028)$ & $659(340-995)$ & $513(250-660)$ & $462(270-566)$ \\
\hline $\mathrm{Cl}^{-}$ & $171(71-231.9)$ & $200.3(103-282.2)$ & $159(66.3-272)$ & $355.5(122-976)$ & $287(92-532.5)$ \\
\hline $\mathrm{Pb}$ total & $0.15(0.01-0.37)$ & $0.16(0.01-0.59)$ & $0.13(0.01-0.57)$ & $0.22(0.01-0.60)$ & $0.17(0.03-0.72)$ \\
\hline $\mathrm{Pb}$ dissolved & $0.10(0-0.13)$ & $0.13(0-0.13)$ & $0.12(0-0.55)$ & $0.12(0-0.39)$ & $0.14(0.02-0.65)$ \\
\hline $\mathrm{Zn}$ total & $0.12(0-0.59)$ & $0.10(0-0.38)$ & $0.08(0-0.26)$ & $0.14(0-0.58)$ & $0.11(0-0.32)$ \\
\hline $\mathrm{Zn}$ dissolved & $0.07(0-0.20)$ & $0.09(0-0.20)$ & $0.06(0-0.23)$ & $0.09(0-0.27)$ & $0.08(0-0.24)$ \\
\hline Cd total & $0.04(0-0.09)$ & $0.04(0-0.10)$ & $0.02(0-0.06)$ & $0.02(0-0.10)$ & $0.02(0-0.08)$ \\
\hline Cd dissolved & $0.03(0-0.07)$ & $0.02(0-0.08)$ & $0.01(0-0.06)$ & $0.01(0-0.85)$ & $0.02(0-0.08)$ \\
\hline Ni total & $0.13(0-0.78)$ & $0.10(0-0.32)$ & $0.06(0-0.17)$ & $0.06(0-0.13)$ & $0.09(0-0.16)$ \\
\hline Ni dissolved & $0.09(0-0.51)$ & $0.06(0-0.22)$ & $0.05(0-0.02)$ & $0.04(0-0.86)$ & $0.05(0-0.10)$ \\
\hline Mn total & $0.15(0-0.33)$ & $0.16(0-0.63)$ & $0.11(0-0.30)$ & $0.14(0.04-0.24)$ & $0.15(0.06-0.32)$ \\
\hline Mn dissolved & $0.12(0-0.29)$ & $0.13(0-0.56)$ & $0.06(0-0.16)$ & $0.12(0-0.22)$ & $0.12(0.03-0.24)$ \\
\hline Fe total & $3.01(0.09-5.41)$ & $4.81(2.1-18.2)$ & $6(1.67-29.8)$ & $3.01(0.10-5.41)$ & $11.5(2.7-80.4)$ \\
\hline Fe dissolved & $2.49(0.07-4.11)$ & $2.42(0.02-3.47)$ & $4.21(1.30-16.52)$ & $2.06(0.09-2.98)$ & $3.67(0.18-12.96)$ \\
\hline Cu total & $0.13(0-0.36)$ & $0.12(0-0.33)$ & $0.11(0.02-0.28)$ & $0.13(0.01-0.23)$ & $0.11(0.01-0.29)$ \\
\hline $\mathrm{Cu}$ dissolved & $0.10(0-0.33)$ & $0.09(0-031)$ & $0.08(0-0.23)$ & $0.10(0.01-0.21)$ & $0.25(0.01-1.71)$ \\
\hline Cr total & $0.03(0-0.31)$ & $0.06(0-0.26)$ & $0.03(0-0.17)$ & $0.02(0-0.13)$ & $0.06(0-0.42)$ \\
\hline Cr dissolved & $0.03(0-0.27)$ & $0.03(0-0.25)$ & $0.02(0-0.16)$ & $0.01(0-0.06)$ & $0.01(0-0.05)$ \\
\hline ICA & $4.0(2.2-7.6)$ & $2.3(0.9-3.1)$ & $3.3(2.2-4.2)$ & $1.5(0.6-2.2)$ & $1.5(0.6-2.2)$ \\
\hline
\end{tabular}

by organic matter pollution (Angeli 1979). Among crustaceans (Table 3), nauplii were dominant, cyclopoid copepods outnumbered calanoids, and cladocerans were mainly represented by non-planktonic species (macrothricids and chydorids).

The mean densities of Chlorophyceae, Bacillariophyceae, Euglenophyceae, Xanthophyceae, and rotifers were higher in S3 (Table 3). The minimum values of total zooplankton were observed in S5 (Table 3), a river zone strongly affected by the discharge of industrial effluents. S1 and S3 presented an alternation of green algae and Cyanophyceae, while S2 and mainly S4, showed a marked preponderance of the Cyanophyceae, in correspondence with higher concentration of DIN and BOD $_{5}$. Crustacean groups showed maximum densities in S1 (Table 3), where more favorable conditions were detected: lowest mean levels of $\mathrm{NH}_{4}{ }^{+}-\mathrm{N}$ and $\mathrm{POC}$, relatively not so low DO values (Table 1), and minimum mean density of Cyanophyceae (Table 3 ). 
Table 2. Selected significant nonparametric correlations among biotic and abiotic variables. $\mathrm{N}=$ number of values for each pair of variables, $\mathrm{R}=$ Spearman's coefficient. TEM: temperature, $\mathrm{CYC}$ : cyclopoids, NAU: nauplii, CLA: cladocerans, ROT: rotifers, CHLO: Chlorophyceae, BACI: Bacillariophyceae, CYA: Cyanophyceae, EU: Euglenophyceae, d: dissolved.

\begin{tabular}{|c|c|c|c|c|c|c|c|c|c|c|c|}
\hline Variable pair & $\mathrm{N}$ & $\overline{\mathrm{R}}$ & P-level & Variable pair & $\mathrm{N}$ & $\mathrm{R}$ & P-level & Variable pair & $\bar{N}$ & $\mathrm{R}$ & P-level \\
\hline NO3N-DO & 50 & 0.66 & $1 . E^{-7}$ & $\overline{\text { CYC-NAU }}$ & 45 & 0.79 & $1 . \mathrm{E}^{-10}$ & NAU-DO & 45 & 0.56 & $1 . \mathrm{E}^{-4}$ \\
\hline NO2N-DO & 50 & 0.60 & $5 . E^{-6}$ & CLA-NAU & 45 & 0.79 & 2. $\mathrm{E}^{-10}$ & CYC-DO & 45 & 0.50 & 4. $\mathrm{E}^{-4}$ \\
\hline $\mathrm{NH} 4{ }^{+} \mathrm{N}-\mathrm{DO}$ & 50 & -0.54 & $5 . \mathrm{E}^{-5}$ & CLA-CYC & 45 & 0.60 & $1 . \mathrm{E}^{-5}$ & ROT-DO & 45 & 0.50 & $5 . \mathrm{E}^{-4}$ \\
\hline $\mathrm{NO} 2 \mathrm{~N}-\mathrm{NO} 3 \mathrm{~N}$ & 50 & 0.55 & $3 \cdot E^{-5}$ & NAU-ROT & 45 & 0.44 & $2 . \mathrm{E}^{-3}$ & CLA-DO & 45 & 0.46 & $1 . \mathrm{E}^{-3}$ \\
\hline $\mathrm{NH}^{\dagger}{ }^{\dagger} \mathrm{N}-\mathrm{NO} 3 \mathrm{~N}$ & 50 & -0.46 & 7. $\mathrm{E}^{-4}$ & CYC-ROT & 45 & 0.52 & $3 . \mathrm{E}^{-4}$ & CHLO-DO & 40 & 0.45 & $3 \cdot E^{-3}$ \\
\hline DO-COD & 39 & -0.75 & 4. $\mathrm{E}^{-8}$ & CLA-ROT & 45 & 0.31 & 0.03 & EU-DO & 40 & 0.33 & 0.03 \\
\hline $\mathrm{DO}-\mathrm{BOD}_{s}$ & 35 & -0.50 & $2 \cdot \mathrm{E}^{-3}$ & CHLO-BACI & 40 & 0.61 & $3 \cdot E^{-5}$ & TEM-ROT & 45 & 0.42 & $4 \cdot E^{-3}$ \\
\hline $\mathrm{COD}^{-\mathrm{BOD}_{5}}$ & 35 & 0.55 & 7. $E^{-4}$ & CYA-CHLO & 40 & 0.43 & $5 . E^{-3}$ & TEM-BACI & 40 & 0.37 & 0.02 \\
\hline $\mathrm{DO}-\mathrm{Cl}^{-}$ & 50 & -0.46 & 8. $E^{-4}$ & CHLO-EU & 40 & 0.43 & $6 . \mathrm{E}^{-3}$ & TEM-CYA & 40 & 0.42 & $7 \cdot \mathrm{E}^{-3}$ \\
\hline $\mathrm{DO}-\mathrm{Ca}^{2+}$ & 50 & -0.32 & 0.02 & BACI-EU & 40 & 0.40 & 0.011 & TEM-EU & 40 & 0.38 & 0.02 \\
\hline $\mathrm{DO}-\mathrm{pH}$ & 50 & 0.54 & 4. $E^{-5}$ & CHLO-ROT & 36 & 0.41 & 0.012 & ICA-NAU & 45 & 0.44 & $2 \cdot \mathrm{E}^{-3}$ \\
\hline DO-HCO3- & 50 & 0.35 & 0.012 & EU-ROT & 36 & 0.35 & 0.04 & ICA-CLA & 45 & 0.52 & $3 \cdot E^{-4}$ \\
\hline DO-POC & 50 & -0.28 & 0.047 & BACI-ROT & 36 & 0.42 & 0.011 & Cdd-ROT & 43 & 0.52 & 4. $E^{-4}$ \\
\hline COD-SM & 39 & 0.35 & 0.03 & BACI-CYC & 36 & 0.36 & 0.03 & $\mathrm{~Pb}$ d-ROT & 43 & 0.43 & $4 \cdot E^{-3}$ \\
\hline $\mathrm{Pb} d-\mathrm{Cd} d$ & 48 & 0.46 & 1. $\mathrm{E}^{-3}$ & & & & & Znd-ROT & 43 & 0.31 & 0.04 \\
\hline $\mathrm{Pb} \mathrm{d}-Z n \mathrm{~d}$ & 48 & 0.49 & 4. $E^{-4}$ & & & & & Znd-BACI & 39 & 0.33 & 0.04 \\
\hline Znd-Cd d & 48 & 0.30 & 0.03 & & & & & $\% \mathrm{I}-\mathrm{Ni} \mathrm{d}$ & 48 & 0.31 & 0.03 \\
\hline
\end{tabular}

Table 3. Mean densities of the algal classes (ind. $\mathrm{mL}^{-1}$ ) and zooplankton groups (ind. $\mathrm{L}^{-1}$ ) in each sampling site and general means.

\begin{tabular}{lrrrrrr}
\hline & $\mathrm{S} 1$ & $\mathrm{~S} 2$ & $\mathrm{~S} 3$ & $\mathrm{~S} 4$ & $\mathrm{~S} 5$ & Mean \\
\hline Cyanophyceae & 5,321 & 11,783 & 10,717 & 10,689 & & 9,628 \\
Chlorophyceae & 5,727 & 6,423 & 14,143 & 7,211 & & 8,376 \\
Bacillariophycea & 5,467 & 2,610 & 11,373 & 3,855 & & 5,826 \\
Euglenophyceae & 776 & 381 & 1,755 & 929 & & 960 \\
Xanthophyceae & 339 & 119 & 660 & 369 & & 372 \\
Dinophyceae & 21 & 0 & 9 & 0 & & 7 \\
PHYTOPLANKTON & 17,617 & 21,315 & 38,656 & 23,053 & & 25,160 \\
\hline Nauplii & 22.62 & 2.5 & 6.95 & 1.53 & 0.02 & 6.73 \\
Cyclopoida & 1.57 & 0.19 & 1.13 & 0.62 & 0.01 & 0.70 \\
Calanoida & 0 & 0.004 & 0.003 & 0 & 0 & 0.001 \\
Cladocera & 2.61 & 0.34 & 0.02 & 0.01 & 0 & 0.60 \\
Crustacea & 27.03 & 3.06 & 8.11 & 2.16 & 0.03 & 8.08 \\
Rotifera & 46.03 & 311.46 & $1,976.08$ & 286.50 & 11.02 & 526.22 \\
ZOOPLANKTON & 73.06 & 314.53 & $1,984.19$ & 288.66 & 11.05 & 534.30 \\
\hline
\end{tabular}

Chlorophyceae had positive correlations with Cyanophyceae, Bacillariophyceae, and Euglenophyceae, as well as the two last ones between each other (Table 2). The algal classes showed a positive correlation with temperature, except for Chlorophyceae (Table 2). High relative densities of the blue-green Merismopedia tenuissima Lemm occurred in S2 during the warm months: January (43\%) and November $(82 \%)$, in coincidence with low values of heavy metals $(\mathrm{Pb}, \mathrm{Zn}, \mathrm{Cd}, \mathrm{Ni}, \mathrm{Cu}$, and $\mathrm{Cr})$ and anoxic conditions. This species shows great growth in eutrophic water bodies with low flow velocities and high temperatures (Pridmore and Ethevedge 1987). A high relative density (56\%) of the centric diatom Cyclotella meneghiniana Kutz was recorded in S3 (December), in coincidence with oversaturation of DO. 
Cladoceran, nauplii, cyclopoid and rotifer densities were positively correlated among them (Table 2). The last group was also directly associated with temperature and algal classes, except for Cyanophyceae. Zooplankton groups, Chlorophyceae and Euglenophyceae, showed a direct correlation with DO (Table 2), suggesting that algal oxygen contribution may be relevant for zooplankton development in an environment with so low DO values. Only two of the plankton groups showed direct correlations with ICA index: cladocerans and nauplii. Cladocerans and calanoids seems to be the more sensible metazoans to mixed pollution (Angeli 1979).

A strong direct correlation between the total and the dissolved form of each heavy metal was detected $(R=0.80-0.97)$. In all sampling sites on several opportunities the concentrations of total and dissolved heavy metals (Table 1) exceeded the guide levels for the protection of aquatic life, stated by the Argentine Dangerous Wastes Law (no. 24051). However, positive correlations were detected with some plankton groups: Bacillariophyceae with $\mathrm{Zn}$, and rotifers with $\mathrm{Pb}, \mathrm{Cd}$ and $\mathrm{Zn}$ (Table 2). Algal growth inhibition by metals raised maximal values around $40 \%$ at all sites, except S4 (87\%) (Fig. 2). There was not evident relationship between the \%I and each metal concentration (Fig. 2), except with nickel (Table 2). Antagonic effects among some metal ions (Rachlin and Grosso 1993), the presence of particles and complexing agents, as organic matter, and the high $\mathrm{Ca}^{2+}$ concentrations, could be possible explanations for reduced heavy metal toxicity (Wang 1987). The average \% I was low (13\%), with higher means in S1 and S2 (around 17\%) and the lowest in S5 (9\%), probably due to the reduction in toxicity by increased nutrient levels (Table 1) and a DIN/SRP more favorable for algal growth (5.7) toward the last site.

According to ICA index, water quality was more deteriorated in S2, S4 and S5. Although conservative ions decreased in S5 with respect to $\mathrm{S} 4$, high values of $\mathrm{NH}_{4}^{+}-\mathrm{N}$ and $\mathrm{POC}$, and anoxia were recorded, conditioning the disappearance of some zooplankton groups, as well as minimum densities of the rest of them (Table 3). In spite of the high contaminant level, no mutagenicity effect on Salmonella typhimurium (Table 4), as well as no strong heavy metal inhibition of algal growth were observed. These results differed from some obtained in S4 and S5 in 1995-1996 (López et al. 1998), when genotoxic effects were detected in XAD2 extracts.

Table 4. Mutagenicity test without or with $(+S 9)$ microsomal activation. The results were expressed as the mean number (June and August) of revertant colonies per plate \pm SD for 0.1 $\mathrm{mL}$ of filtrate water samples or XAD2 extracts (EX). Control: $\mathrm{NaCl} 0.9 \%$ solution.

\begin{tabular}{ccccccccc}
\hline Sample & TA98 & TA9+S9 & TA100 & TA100+S9 & TA98EX & TA98+S9EX & TA100EX & TA100+S9EX \\
\hline Control & $41 \pm 3$ & $43 \pm 5$ & $121 \pm 12$ & $135 \pm 17$ & $45 \pm 2$ & $48 \pm 5$ & $135 \pm 11$ & $143 \pm 16$ \\
S2 & $39 \pm 4$ & $42 \pm 3$ & $110 \pm 10$ & $125 \pm 08$ & $47 \pm 4$ & $49 \pm 6$ & $129 \pm 13$ & $138 \pm 08$ \\
S4 & $43 \pm 2$ & $38 \pm 7$ & $105 \pm 09$ & $109 \pm 11$ & $46 \pm 5$ & $51 \pm 3$ & $122 \pm 15$ & $141 \pm 09$ \\
S5 & $44 \pm 5$ & $40 \pm 9$ & $118 \pm 15$ & $129 \pm 09$ & $43 \pm 5$ & $46 \pm 8$ & $131 \pm 10$ & $139 \pm 09$ \\
\hline
\end{tabular}

Some water quality variables improved in S3, where the highest concentrations of DO and the minimum values of $\mathrm{COD}, \mathrm{BOD}_{5}$, conductivity, and $\mathrm{Cl}^{-}$were recorded (Table 1). S3 showed a secondary increase in cyclopoids and nauplii, but also maximal mean densities of most of the phytoplankton groups and rotifers (Table 3), with conspicuous growth of organisms associated with organic pollution (mainly Brachionus, Polyarthra, and Bdelloid species) (Angeli 1979). This site is located at the beginning of the river channeling, within an extensive area of woods and pastures, downstream of the mouth of Las Ortegas Stream, which flows through flooded 

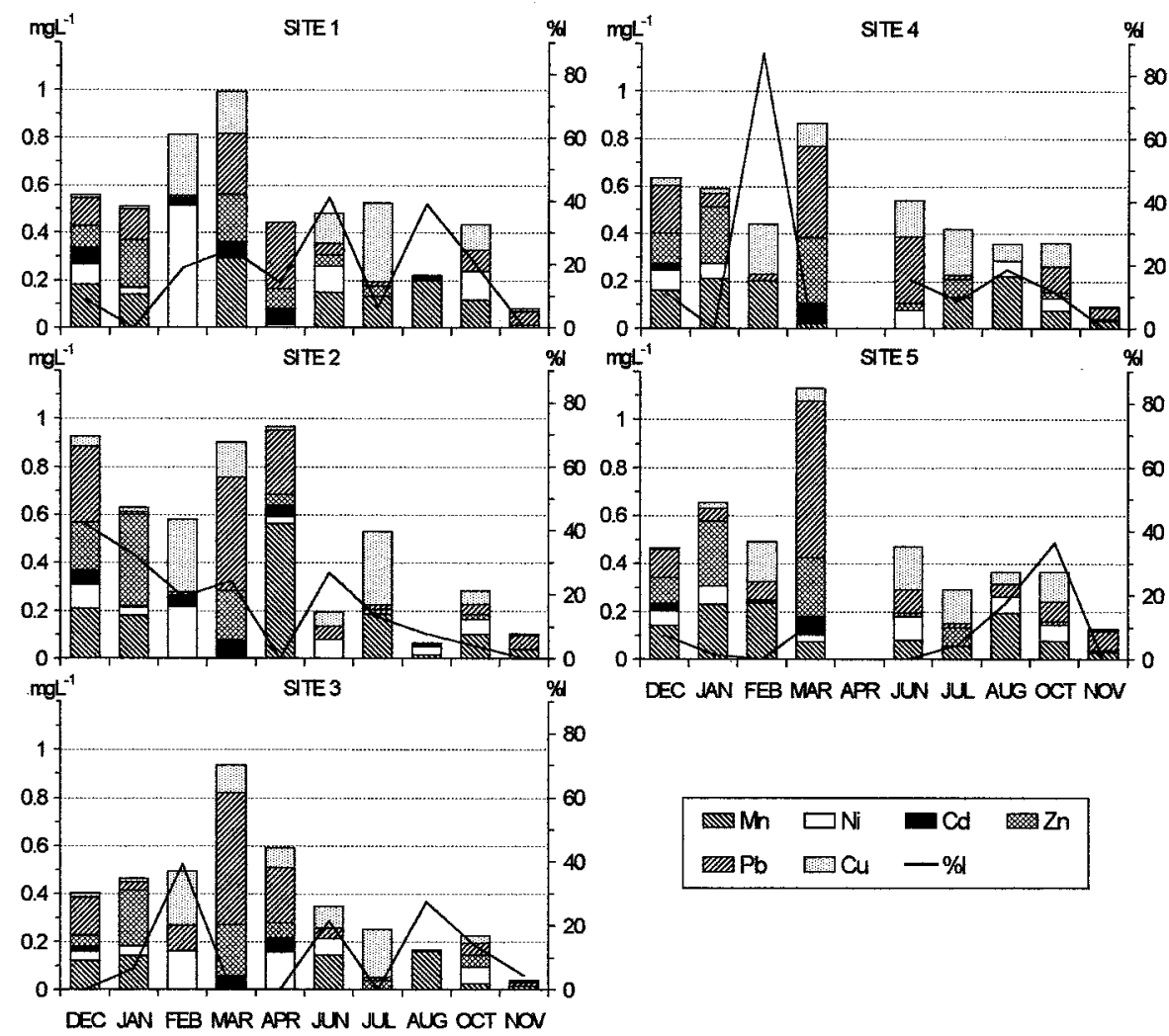

DEC JAN FEB MAR APR JUN JUL AUG OCT NON

80

$\begin{array}{llll}\mathrm{Mn} & \square \mathrm{Ni} & \mathrm{Cd} & \mathrm{Zn} \\ \mathrm{Pb} & \mathrm{Cu} & -\%\end{array}$

Figure 2. Dissolved heavy metal concentrations and \% $\mathrm{I}$. $\mathrm{Fe}$ and $\mathrm{Cr}$ were not considered.

soils with macrophytes, and may thus contribute to the relative improvement of the water quality of the river (Gómez 1998).

Water pollution was mainly reflected in this river by low dissolved oxygen concentration, high levels of nutrients, suspended matter, and heavy metals, that exceeded the national guide levels. Thus, decrease of crustaceans, and conspicuous growth of opportunistic organisms, that decreases in most critical conditions, were observed in the plankton. At the present, recovery plans for this highly polluted river only focus on the cleaning of the river bed. However, the results obtained suggest that a definitive recovery should also rely on a decrease of the crude effluent input and on a vegetal cover restoration of the surrounding lands.

The lack of strong heavy metal inhibition of algal growth and of mutagenicity effects suggests that different factors may reduce heavy metal toxicity in this river. Efficiency of water treatment technology is usually evaluated by the reduction in total concentration of contaminants. However, caution is required because the removal of adsorption factors, such as organic carbon or clays, may increase bioavailability of residual contaminants (Burton et al. 1992).

Acknowledgments. This research was part of the UBACYT IG03 integrated Proyect. 


\section{REFERENCES}

Angeli N (1979) Influencia de la polución del agua sobre los elementos del plancton. In: Pesson P (ed) La contaminación de las aguas continentales. Incidencias sobre las biocenosis acuáticas. MundiPrensa, Madrid:115-158

APHA (1995) Standard Methods for the Examination of Water and Wastewater. 19th od. APHAAWWA-WPCF, Washington DC

Berón L (1984) Evaluación de la calidad de las aguas de los ríos de la Plata y Matanza - Riachuelo mediante la utilización de índices de calidad de agua. Secretaría de Vivienda y Ordenamiento Ambiental. Ministerio de Salud y Acción Social, Buenos Aires

Braile PM, Cabalcanti JE (1993) Manual de Tratamento de àguas residuàrias industriais. CETESB (Companhia de Tecnologia de Saneamento Ambiental):83-86

Burton GAJr, Scott KJ (1992) Sediment toxicity evaluations. Their niche in ecological assessment. Environ Sci Technol 26:2068-2075

Castañé P, Loez C, Olguín H, Puig A, Rovedatti M, Topalián ML, Salibián A (1998) Caracterización y variación espacial de parámetros físicoquímicos y del plancton en un río urbano contaminado (Río Reconquista, Argentina). Rev Int Contam Ambient 14:69-77

Descy JP (1987) Phytoplankton composition and dynamics in the river Meuse (Belgium). Arch Hydrobiol Suppl 78:225-245

Golterman H, Clymo R, Ohndtad M (1978) Methods for the physical and chemical examination of freshwaters. Blackwell Sci Publ, Oxford

Gómez N (1998) Use of epipelic diatoms for evaluation of water quality in the Matanza-Riachuelo (Argentina), a pampean plain river. Wat Res 32:2029-2034

Hanazato T, Yasuno M (1990) Influence of time of application of an insecticide on recovery patterns of a zooplankton community in experimental ponds. Arch Environ Contam Toxicol 19:77-83

Lewis WMJr (1979) Zooplankton community analysis: Studies on a Tropical System. Springer-Verlag, New York

López L, Magdaleno A, de Cabo L, Noriega MF, Bassi M, Arreghini S, Bassols G, Wagner M, Moretton J (1998) Estudios de mutagenicidad, inhibición del crecimiento algal y contaminación química en aguas superficiales de un río urbano de Buenos Aires, Argentina. Rev Int Contam Ambient 14:27-37

Maron D, Ames BN (1983) Revised methods for the Salmonella mutagenicity test. Mut Res 113:173215

Miller WE, Greene JC, Shiroyama T (1978) The Selenastrum capricornutum (Printz) algal assay bottle test: Experimental design, application, and data interpretation protocol. EPA-600/9-78-018. U. S. Environmental Protection Agency, Corvallis, OR

Olson D, Dinerstein E, Canevari P, Davidson I, Castro G, Morisset V, Abell R, Toledo E (1998) Freshwater biodiversity of Latin America and the Caribbean: A conservation assessment. Biodiversity Support Program, Washington DC

Pridmore RD, Ethevedge MK (1987) Planktonic cyanobacteria in New Zealand inland waters: distribution and population dynamics. New Zealand J Mar Freshw Res 21:491-502

Rachlin JW, Grosso A (1993) The growth response of the green alga Chlorella vulgaris to combined divalent cation exposure. Arch Environ Contam Toxicol 24:16-20

Sournia A (1978) Phytoplankton Manual. Monographs of oceanographic methodology. UNESCO, Paris

U.S. Environmental Protection Agency (1994) Short-term methods for estimating the chronic toxicity of effluents and receiving water to freshwater organisms. EPA/600/4-91/002

Utermöhl H (1958) Zur Vervollkommnong der quantitativen Phytoplankton metodik. Mitt Int Ver Limnol 9:1-38

Vázquez MA, Moretton J (1995) Detección de agentes genotóxicos en efluentes de la industria gráfica. Rev Int Contam Ambient 11:99-103

Wang W (1987) Factors affecting metal toxicity to (and accumulation by) aquatic organisms Overview. Environ Int 13:437-457 